\title{
Glucose Clearance Measurement
}

National Cancer Institute

\section{Source}

National Cancer Institute. Glucose Clearance Measurement. NCI Thesaurus. Code C96652.

A measurement of the glucose clearance in a sample. 